Medal and was a President of the Glasgow Royal Medico-Chirurgical Society. He retired from active hospital work at the age of sixty and went to live in St. Andrews. His enthusiasm for clinical activities of all kinds found fitting expression in his devotion to the Mackenzie Institute for Clinical Research which had been founded by his friend, Sir James' Mackenzie in St. Andrews. The published reports of the Institute bear witness to the thought and energy which Ramsay put into a project which had such a close parallel in clinical medicine to his own ideals in clinical ophthalmology. Both the Tennent Institute and the Mackenzie Institute had to curtail their activities in 1939 but fortunately neither suffered great material damage. The Charlotte Street clinic where Ramsay worked so hard as a young man was destroyed by enemy action.

From his beautiful home in St. Andrews he retained his ophthalmological contacts and interests to the end. He was in correspondence with many friends and colleagues throughout the world, and the hospitality of Dr. and Mrs. Maitland Ramsay was a feature of the most academic town in Scotland. He was always pleased to hear of fresh activities in the world of ophthalmology and was delighted to yarn by the fireside on the events of the past and the plans for the future. The trend of modern medicine was in general distasteful to him. He feared the bureaucrat and the organiser of clinical work. Anything which was in the least likely to interfere with the personal relationship between the patient and a trusted medical adviser was anathema to him, and rightly so. Patients loved him and he gave himself wholeheartedly to their service; even after his retirement from active practice in Glasgow, many made the journey to St. Andrews to consult with one of ripe wisdom and wide culture. The charm and geniality of his manner will long be remembered by the generation of students whom he trained; the generations to come will read the papers of a great clinical observer with benefit and understanding. He applied in his practice the best that is known in our art and maintained throughout his long life an enthusiasm for ophthalmology that has been an inspiration to his younger colleagues.

\title{
JOHN ALEXANDER PRINGLE
}

John Alexander Pringle, Hon. Ophthalmic Surgeon to the Kent and Canterbury Hospital, who died at Epsom on February 12, was born in Ireland, Co. Tyrone, in 1882, and was educated at Coleraine Academy, at the Royal Academy, Belfast, and at Trinity College, Dublin. He graduated in medicine in 1905, and proceeded M.D. of Dublin University in 1908 after holding house appointments in Dublin and at the Bristol Eye Hospital. Coming to London he worked as chief assistant at Moorfields and senior 
ophthalmic assistant at St. Mary's Hospital, and later settled at Canterbury.' During the war of 1914-1918 he was officer in charge of the ophthalmic centre at Rouen, and then ophthalmic surgeon to the 4th Army, B.E.F., and afterwards held the same post in the British Army of the Rhine. On returning to civil life he became eye surgeon to the Ministry of Pensions for the Canterbury District and to the local education authority; he was also consulting ophthalmic surgeon to the Herne Bay Hospital and to Princess Mary's Hospital for Children at Margate.

A colleague writes:-

" He was a keen and careful oculist, a good surgeon and clinician and popular with his patients. He started practice in Canterbury in 1922, and soon worked up a large practice extending over the East Kent area. As regards sport, he was fond of shooting and was a useful golfer, and a member of the Medical Golfing Society. He spent many holidays abroad.

He retired from practice in 1940 on account of heart trouble, from which he never really recovered and he lived quietly in Cornwall during the war years."

\section{NOTES}

Faculty of Ophthalmologists now been elected as follows :-

Regions
1
2
3
4
5
6

E. G. Mackie

P. Jameson Evans

J. J. Healy

Sir Stewart Duke-Elder

J. P. Spencer Walker

W. J. B. Riddell

George Black; R. C. Davenport ; J. H. Doggart; P. G. Doyne; O. M. Duthie; C. B. Goulden; F. A. Juler; Frank W. Law ; T. Keith Lyle; Ida Mann; H. M. Traquair; David Wilson.

\section{Part-time Associate}

C. M. Stevenson.

The Annual General Meeting will be held at the Royal Society of Medicine, 1 Wimpole Street, London, W.1, on Saturday, June 1, at 2.30 p.m. Notices will be sent to each Member and Associate of the Faculty, together with a copy of the Annual Report. 